\title{
GARANȚIILE NEGATIVE
}

\section{Adrian TAMBA*}

Rezumat: Prezenta cercetare, intitulată „Garanțiile negative”, țintește niște ființe juridice extrem de interesante. În principal, ele sunt utilizate de bănci. Cu toate acestea, garanțiile negative pot fi plasate în mâinile unor entități non-bancare; o indică, e.g., First Wyoming Bank, Casper v. Mudge.

Garanțiile negative sunt întâlnite atât în tradiția de Civil Law, cât și în cea de Common Law. Desigur, după creierul meu, Codul civil român îmbrățișează așa-zisele garanții negative, deși nu se servește de o asemenea expresie.

În încheiere, este evidențiat abandonul ortodoxiei: concluziile explicite sunt inobservabile.

Cuvinte cheie: garanții negative, aspecte contractuale, promisiune, act juridic unilateral, Vladimir Hanga.

* Asist. dr., Facultatea de Drept, Universitatea Babeş-Bolyai din Cluj, amba adrian@yahoo.com. 


\section{NEGATIVE PLEDGES}

Abstract: My work, called „Negative Pledges”, aims at some interesting legal beings. Mainly, they are used by banks. Yet, negative pledges may very well be placed in the hands of entities that are not banks; this is pointed out by, e.g., First Wyoming Bank, Casper v. Mudge.

Negative pledges are encountered both in the Civil Law and the Common Law traditions. Of course, it is my view that the Romanian Civil Code embraces the socalled negative pledges, though it does not use such an expression.

At the end of this paper, the abandonment of orthodoxy is highlighted: no explicit conclusions can be noticed.

Key words: negative pledges, contractual aspects, covenant, unilateral juridical act, Vladimir Hanga.

De la bun început, ne exprimăm nădejdea că umila și succinta noastră contribuție este demnă de volumul „Despre (r)evoluție în drept”, închinat minții gigantice ce a fost prof. dr. doc. Vladimir Hanga. Încă ceva: studiul de față nu are, poate, darul să se ridice la rangul de „ființă revoluționară”, dar tragem speranța că este măcar o „entitate” acceptabilă și nicidecum o „creatură” involuată.

1. Expresia „garanții negative” este una pe care doctrina o utilizează pentru a îmbrățişa diverse formule contractuale ce restrâng libertatea de acțiune a debitorului sau îl constrâng pe datornic să-l informeze pe creditor astfel încât să crească șansele plății ${ }^{1}$. Într-adevăr, debitorul se angajează adesea față de creditor să nu facă ceva sau, mai rar, să facă ceva²; garanțiile negative sunt entitățile care se ivesc și pe care nu le putem ocoli.

\footnotetext{
${ }^{1}$ M. Cabrillac, Ch. Mouly, S. Cabrillac, Ph. Pétel, Droit des sûretés, $9^{\mathrm{e}}$ édition, LexisNexis, Paris, 2010, p. 477, nr. 643.

${ }^{2}$ L. Aynès, P. Crocq, Droit des sûretés, 11 édition, LGDJ, Paris, 2017, p. 190, nr. 320.
} 
Un doctrinar de mare însemnătate ne instruiește că garanțiile negative sunt clauze contractuale prin care un debitor își asumă față de creditor angajamente de a nu face, așa încât să nu fie compromisă valoarea gajului general $^{3}$ sau comun 4 . Acelaşi autor adaugă că unui creditor îi poate fi conferit un drept de „vedere” asupra patrimoniului debitorului său5. Chiar dacă, întro fază, Dominique Legeais conectează garanțiile negative de angajamente de a nu face 6 , în secunda în care pomenește dreptul de „vedere” asupra patrimoniului debitorului, el acceptă, cu o mai mare sau mai mică claritate, că garanțiile negative pot fi legate de obligații de a face. $\mathrm{O}$ varietate de garanții negative este înlănţuită de un drept de „vedere” sau de „privire” al creditorului asupra situației patrimoniale a debitorului, fiind în prezența unei obligații de informare pusă în cârca datornicului7; îndatorirea de informare a debitorului este una pozitivă (i.e., de a face sau facere $^{8}$ ), iar creditorul are la îndemână o garanție negativă ce îi permite să „vadă” ce se întâmplă în patrimoniului

3 D. Legeais, Droit des sûretés et garanties du crédit, $13^{\mathrm{e}}$ édition, LGDJ, Paris, 2019, p. 33, nr. 23.

4 În „Vocabulaire juridique” citim că bunurile debitorului (i.e., ansamblul bunurilor sale prezente și viitoare) sunt „gajul comun” al creditorilor lui, cei din urmă bucurându-se de un „drept de gaj general”. A se vedea, G. Cornu (sous la direction de), Vocabulaire juridique, Association Henri Capitant, 9e édition „Quadrige”, Presses Universitaires de France, Paris, 2011, p. 482.3.

5 D. Legeais, Droit des sûretés et garanties du crédit, p. 33, nr. 23.

${ }^{6}$ D. Legeais, Droit des sûretés et garanties du crédit, p. 33, nr. 23 („[l]es sûretés négatives sont des clauses contractuelles par lesquelles un débiteur prend des engagements de ne pas faire à l'égard de son créancier ...”; subl. ns., A.T.).

7 A se vedea, Ph. Simler, Ph. Delebecque, Droit civil. Les sûretés. La publicité foncière, $7^{\mathrm{e}}$ édition, Dalloz, Paris, 2016, p. 24, nr. 33.

8 Specialiștii în materie de drept al obligațiilor susțin că obligația de a face este cea prin care debitorul se angajează să îndeplinească un fapt pozitiv, să execute o prestație oarecare. A se vedea, Ph. Malinvaud, D. Fenouillet, Droit des obligations, $11^{\mathrm{e}}$ édition, LexisNexis, Paris, 2010, p. 8, nr. 16 . 
debitorului său sau să fie informat cu privire la starea patrimonială a celui cei este îndatorat.

Probabil că, frecvent, garanțiile negative sunt aspecte contractuale sau convenționale; garanțiile negative sunt încătușate de sintagme precum „formule contractuale”, „debitorul se angajează față de creditor” (sugerându-se ființarea unui acord de voințe) sau „clauze ${ }^{11}$ contractuale” ${ }^{12}$. Totuşi, un anumit tip de garanție negativă poate fi înfăşurat în haina unui act juridic unilateral. În ipoteza cesiunii de creanță ${ }^{13}$ (art. 1566-1592 C. civ.), debitorul cedat îi poate opune creditorului cesionar toate excepțiile sau mijloacele de apărare pe care le putea invoca împotriva cedentului ${ }^{14}$ (e.g., condiții și termeni de plată, nulitatea, compensația, rezoluțiunea, excepția de neexecutare) ${ }^{15}$ [art. 1582 alin. (1) C. civ.]. Desigur, practica afacerilor tinde să

${ }^{9}$ A se vedea, M. Cabrillac, Ch. Mouly, S. Cabrillac, Ph. Pétel, Droit des sûretés, p. 477, nr. 643. ${ }^{10}$ A se vedea, L. Aynès, P. Crocq, Droit des sûretés, p. 190, nr. 320.

${ }^{11}$ În viziunea lui Jean Carbonnier, clauza este o porțiune a contractului referitoare la un punct particular; clauza este pentru contract ceea ce articolul este pentru lege. A se vedea, J.

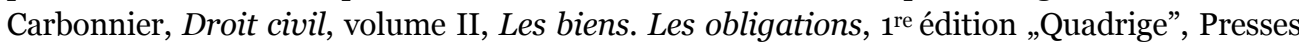
Universitaires de France, Paris, 2004, p. 1942, nr. 930.

12 A se vedea, D. Legeais, Droit des sûretés et garanties du crédit, p. 33, nr. 23.

13 Muriel Fabre-Magnan crede că cesiunea de creanță este o operațiune în trei: cedentul îi cedează cesionarului creanța „deținută” împotriva debitorului cedat. A se vedea, M. FabreMagnan, Droit des obligations, 1 - Contrat et engagement unilatéral, $1^{\text {re }}$ édition, Presses Universitaires de France, Paris, 2008, p. 521, nr. 206. Poate că cesiunea de creanță este o operațiune în trei; ea este, totodată, un contract în doi (i.e., între cedent și cesionar) [art. 1566 alin. (1) C. civ.].

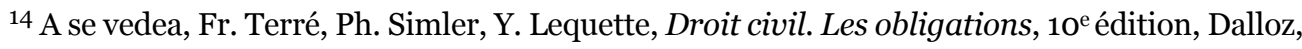
Paris, 2009, p. 1278, nr. 1291.

15 A se vedea, Ph. Malaurie, L. Aynès, Ph. Stoffel-Munck, Droit civil. Les obligations, $2^{\mathrm{e}}$ édition, Defrénois, Paris, 2005, p. 757, nr. 1318. Acești autori fac vorbire despre excepții ce își au originea în contractul care a generat creanța și ne oferă câteva exemple: nulitatea creanței cedate, excepția de neexecutare.

\section{8}


obțină de la debitorul cedat o renunțare la excepțiile ce îi aparțin acestuia ${ }^{16}$; într-adevăr, în domeniul afacerilor, se aşteaptă ca debitorul cedat să renunțe la excepțiile sale. Această renunțare are ca scop garantarea securității operațiunii ${ }^{17}$; deci, îi beneficiază, în primul rând, cesionarului1 ${ }^{18}$. Prin aceea că avem de-a face cu o limitare ${ }^{19}$ a drepturilor debitorului pentru a fi garantate cele ale cesionarului, renunțarea la excepții sau la mijloace de apărare poate fi privită ca o garanție negativă ${ }^{20}$. Sigur că renunțarea poate apuca calea unui act juridic unilateral ${ }^{21}$. La urmă, garanția negativă ce ia forma renunțării debitorului cedat la excepțiile sau mijloacele lui de apărare ar putea fi un act unilateral ${ }^{22}$.

16 A se vedea, Fr.-X. Licari, Une sûreté négative: la renonciation du débiteur cédé à ses exceptions, Revue Lamy Droit civil, 2004, p. 1.

17 A se vedea, Fr.-X. Licari, Une sûreté négative: la renonciation du débiteur cédé à ses exceptions, p. 1.

18 A se vedea, Fr.-X. Licari, Une sûreté négative: la renonciation du débiteur cédé à ses exceptions, p. 1.

19 Renunțarea la excepții, probabil, ar trebui privită ca o limitare a drepturilor debitorului, dacă ne dorim să insistăm asupra perspectivei datornicului. Drepturile sale nu pot fi eliminate în totalitate, căci nu poate renunța la anumite aspecte. E.g., debitorul nu poate renunța la posibilitatea de a invoca caracterul ilicit sau imoral al obiectului sau cauzei contractului generator de creanță. A se vedea, Fr.-X. Licari, Une sûreté négative : la renonciation du débiteur cédé à ses exceptions, p. 11.

${ }^{20}$ A se vedea, Fr.-X. Licari, Une sûreté négative: la renonciation du débiteur cédé à ses exceptions, p. 1.

${ }^{21}$ A se vedea, Fr.-X. Licari, Une sûreté négative: la renonciation du débiteur cédé à ses exceptions, p. 8.

${ }^{22}$ François Terré ne comunică că un act juridic este unilateral dacă efectul juridic înspre care tinde rezultă din manifestarea de voință a unei singure persoane. A se vedea, Fr. Terré, Introduction générale au droit, 8 édition, Dalloz, Paris, 2009, p. 180, nr. 220. Astfel, ar fi acte unilaterale recunoașterea unui copil, testamentul sau diverse acte abdicative precum renunțările la o succesiune, la un uzufruct ori la o servitute. A se vedea, Fr. Terré, Introduction générale au droit, p. 180, nr. 220. 
2. O concepție foarte restrânsă ar reduce garanțiile negative la angajamente ale debitorilor de a nu consimți alte garanții ${ }^{23}$ (e.g., ipoteci) asupra unui bun sau asupra ansamblului bunurilor lor ${ }^{24}$. Într-o orientare extensivă, garanțiile negative ar îngloba toate clauzele care tind să sporească siguranța ${ }^{25}$ creditorului ${ }^{26}$; aceasta este concepția care pare să prevaleze în doctrină ${ }^{27}$. Desigur, în măsura în care ținem seama de epitetul „negative”, ar trebui să reținem doar formulele care îi impun debitorului o abstențiune ${ }^{28}{ }^{29}$ Totuşi, garanțiile negative, mai rar, pot fi înlănțuite de îndatoriri de a face ${ }^{30}$ (supra., nr. 1).

3. Garanțiile negative sunt utilizate mai ales de stabilimente de credit $^{31}$. Intr-adevăr, creditorii ocrotiți de aceste garanții negative sunt, în

23 Într-o lucrare din Québec, lecturăm că garanția negativă constă într-o convenție prin care debitorul se angajează să nu consimtă nicio garanție în favoarea altor creditori și să radieze eventualele garanții legale. A se vedea, É. Lambert, Commentaires sur le Code civil du Québec (DCQ), Les sûretés, volume 1, Gage commun des créanciers, priorités et hypothèques (dispositions générales) (art. 2644 à 2680 C.c.Q.), Éditions Yvon Blais, Cowansville, 2009, p. 34 (Édith Lambert îl citează pe Payette; a se vedea, nota de subsol nr. 65 de la p. 34).

${ }^{24}$ A se vedea, M. Cabrillac, Ch. Mouly, S. Cabrillac, Ph. Pétel, Droit des sûretés, p. 478, nr. 643. 25 Autorul Louis Payette menționează că garanția negativă este un mijloc ce îi permite unui creditor ordinar sau obișnuit să obțină un tratament preferențial. A se vedea, É. Lambert, Commentaires sur le Code civil du Québec (DCQ), Les sûretés, volume 1, Gage commun des créanciers, priorités et hypothèques (dispositions générales) (art. 2644 à 2680 C.c.Q.), Éditions Yvon Blais, Cowansville, 2009, p. 34.

${ }^{26}$ A se vedea, M. Cabrillac, Ch. Mouly, S. Cabrillac, Ph. Pétel, Droit des sûretés, p. 478, nr. 643. 27 A se vedea, M. Cabrillac, Ch. Mouly, S. Cabrillac, Ph. Pétel, Droit des sûretés, p. 478, nr. 643. 28 A se vedea, M. Cabrillac, Ch. Mouly, S. Cabrillac, Ph. Pétel, Droit des sûretés, p. 478, nr. 643. 29 Rose-Noëlle Schütz este de părere că garanțiile negative restrâng dreptul debitorului de a dispune liber de patrimoniul său sau de un anumit bun. A se vedea, R.-N. Schütz, Inaliénabilité, Répertoire de droit civil, 2014, nr. 87. Sintagma „restrâng dreptul debitorului” ne-ar duce cu gândul la prohibiții sau abstențiuni.

${ }^{30}$ A se vedea, L. Aynès, P. Crocq, Droit des sûretés, p. 190, nr. 320.

${ }^{31}$ A se vedea, M. Cabrillac, Ch. Mouly, S. Cabrillac, Ph. Pétel, Droit des sûretés, p. 478, nr. 643. 
principal, entitățile bancare ${ }^{2}$. Garanțiile negative se bucură de o oarecare utilitate. Ele prezintă avantajul de a nu costa nimic33. Egalmente, îi pun creditorului la îndemână un „drept de veto” sau un „drept de vedere ori de privire” (i.e., „droit de regard”)34; cele două drepturi pot fi prețioase35.

Dreptul de veto intră în scenă atunci când, prin garanția negativă, debitorul se angajează să nu facă ceva fără acordul creditorului (e.g., să nu constituie o garanție în favoarea altor creditori ${ }^{36}$; să nu închirieze imobilele sale37; să nu contracteze noi împrumuturi ${ }^{38}$ ). Fiind necesar acordul creditorului, rezultă că acesta se poate opune diverselor operațiuni în care debitorul ar fi tentat să se implice şi le poate bloca; astfel, creditorul se bucură de un drept de veto.

Dreptul de „vedere” sau de „privire” își face apariţia în momentul în care garanția negativă este încătuşată de o obligație de informare. Presupunând că debitorul se îndatorează să-i furnizeze creditorului său informații referitoare la modificările pe care le operează asupra patrimoniului, cel din urmă ${ }^{39}$ este înarmat cu o panoramă sau priveliște ce vizează universalitatea juridică a debitorului.

${ }^{32}$ A se vedea, R.-N. Schütz, Inaliénabilité, Répertoire de droit civil, 2014, nr. 87.

33 A se vedea, M. Cabrillac, Ch. Mouly, S. Cabrillac, Ph. Pétel, Droit des sûretés, p. 478, nr. 643. 34 A se vedea, M. Cabrillac, Ch. Mouly, S. Cabrillac, Ph. Pétel, Droit des sûretés, p. 478, nr. 643. 35 A se vedea, M. Cabrillac, Ch. Mouly, S. Cabrillac, Ph. Pétel, Droit des sûretés, p. 478, nr. 643. ${ }^{36}$ A se vedea, M. Cabrillac, Ch. Mouly, S. Cabrillac, Ph. Pétel, Droit des sûretés, p. 478, nr. 644. De asemenea, a se vedea, D. Legeais, Droit des sûretés et garanties du crédit, p. 33, nr. 23 („ne pas constituer de sûreté sur un bien donné").

37 A se vedea, L. Aynès, P. Crocq, Droit des sûretés, p. 190, nr. 320.

${ }^{8}$ A se vedea, R.-N. Schütz, Inaliénabilité, Répertoire de droit civil, 2014, nr. 87 („ne pas contracter de nouveaux emprunts").

39 Dominique Legeais ne înștiințează că o garanție negativă poate să prevadă un drept de „vedere” sau de „privire” al creditorului asupra afacerilor debitorului său. A se vedea, D. Legeais, Sûretés, Répertoire de droit civil, 2016, nr. 23.

\section{1}


Câteodată, garanțiile negative pot fi problematice. Ele facilitează ingerința bancherului în afacerile clientului său și traduc juridic omnipotența economică a distribuitorului de credit, ceea ce, în anumite cazuri, le-ar putea face abuzive ${ }^{40}$.

4. Stipulațiile pe care le putem califica drept garanții negative au o interesantă trăsătură: diversitatea ${ }^{41}$. Bineînțeles, ele pot fi grupate în funcţie de aspectul pe care îl vizează: aceste garanții negative pot afecta un bun determinat ${ }^{42}$ sau ansamblul patrimoniului 43 .

În prezența unei garanţii negative ce afectează un bun determinat ne vom afla în clipa în care debitorul se angajează să nu facă, fără acordul creditorului, anumite operațiuni privitoare la un bun specific, cel mai des fiind vorba despre lucrul a cărui dobândire a finanțat-o creditorul ${ }^{44}$. Operațiunile interzise sunt, fie cumulativ, fie selectiv, următoarele: înstrăinarea, constituirea de garanții etc45.

Într-adevăr, debitorul se poate îndatora față de creditor să nu vândă, să nu închirieze sau să nu ipotecheze fără acordul creditorului anumite imobile cât timp cel dintâi are calitatea de datornic ${ }^{46}$.

\footnotetext{
40 A se vedea, L. Aynès, P. Crocq, Droit des sûretés, p. 191, nr. 320.

${ }^{41}$ A se vedea, Ph. Simler, Ph. Delebecque, Droit civil. Les sûretés. La publicité foncière, p. 24, nr. 33 .

${ }^{42}$ A se vedea, M. Cabrillac, Ch. Mouly, S. Cabrillac, Ph. Pétel, Droit des sûretés, p. 478, nr. 644. 43 A se vedea, M. Cabrillac, Ch. Mouly, S. Cabrillac, Ph. Pétel, Droit des sûretés, p. 480, nr. 645. 44 A se vedea, M. Cabrillac, Ch. Mouly, S. Cabrillac, Ph. Pétel, Droit des sûretés, p. 478, nr. 644. 45 A se vedea, M. Cabrillac, Ch. Mouly, S. Cabrillac, Ph. Pétel, Droit des sûretés, p. 478, nr. 644. ${ }^{46}$ A se vedea, L. Aynès, P. Crocq, Droit des sûretés, p. 190-191, nr. 320.
} 
Garanția negativă se poate manifesta ca o clauză pari passu: debitorul se angajează să nu-i acorde altui creditor o garanție (e.g., o ipotecă) fără să-i propună același avantaj creditorului-beneficiar al garanției negative ${ }^{47}$.

Pe tărâmul unei garanții negative care afectează ansamblul patrimoniului ne vom situa în ipoteze precum acestea: debitorul se angajează să nu modifice activul patrimoniului său ${ }^{48}$ sau să nu augmenteze pasivul patrimonial prin contractarea unui împrumut 49 .

Tot o garanție negativă ce afectează întregul patrimoniu este cea asociată dreptului de „vedere” sau de „privire” asupra universalităţii juridice a debitorului, în spinarea datornicului fiind pusă o obligație de informare referitoare la starea patrimoniului său. Cu adevărat, debitorul se poate obliga să-l informeze pe creditor în privința modificărilor pe care își propune să le efectueze asupra patrimoniului său ${ }^{50}$.

În sfârşit, debitorului îi este posibil să se îndatoreze faţă de creditorul lui să nu constituie garanții personale ${ }^{51}$ (e.g., o fideiusiune ${ }^{52}$ ). Iată întrebarea: o astfel de garanție negativă afectează un anumit bun ori ansamblul

47 A se vedea, D. Legeais, Droit des sûretés et garanties du crédit, p. 33, nr. 23; L. Aynès, P. Crocq, Droit des sûretés, p. 191, nr. 320.

${ }^{48}$ A se vedea, M. Cabrillac, Ch. Mouly, S. Cabrillac, Ph. Pétel, Droit des sûretés, p. 480, nr. 645. 49 A se vedea, M. Cabrillac, Ch. Mouly, S. Cabrillac, Ph. Pétel, Droit des sûretés, p. 480, nr. 645. $5^{\circ}$ A se vedea, M. Cabrillac, Ch. Mouly, S. Cabrillac, Ph. Pétel, Droit des sûretés, p. 480, nr. 645. ${ }^{51}$ A se vedea, Ph. Simler, Ph. Delebecque, Droit civil. Les sûretés. La publicité foncière, p. 24, nr. 33 („de ne pas constituer d'autres sûretés ... personnelles”).

$5^{2}$ Fideiusiunea nu este decât o garanție personală ce nu-i conferă creditorului nici drept de urmărire, nici drept de preferință asupra bunurilor fideiusorului. A se vedea, H. et L. Mazeaud, J. Mazeaud, Fr. Chabas, Leçons de droit civil, tome III, premier volume, Sûretés. Publicité foncière, $7^{\mathrm{e}}$ édition (par Y. Picod), Montchrestien, Paris, 1999, p. 9, nr. 4. Sigur, contractul de fideiusiune propriu-zis este cel prin care fideiusorul se obligă față de creditor să plătească datoria debitorului. A se vedea, Ph. Simler, Cautionnement. Garanties autonomes. Garanties indemnitaires, $5^{\mathrm{e}}$ édition, LexisNexis, Paris, 2015, p. 21, nr. 16.

\section{3}


patrimoniului? Mecanismul garanției personale îi conferă creditorului un drept de acțiune contra unuia sau mai multor debitori suplimentari53; creditorul dispune de $o$ acțiune împotriva altui patrimoniu ${ }^{54}$ ori în contra altor patrimonii. Astfel, mai multe patrimonii „răspund” de aceeaşi datorie55: patrimoniul debitorului și patrimoniul ori patrimoniile garantului personal sau garanţilor personali (i.e., debitorului suplimentar sau debitorilor suplimentari). În funcție de natura garanției, după cum afectează ansamblul patrimoniului global al unei persoane sau un bun în particular, vom distinge între garanțiile personale și cele reale ${ }^{56}$. Finalmente, garanțiile personale ${ }^{57}$ aduc cu ele alte patrimonii, nu un bun specific sau determinat. Atunci când

53 A se vedea, A.-S. Barthez, D. Houtcieff, Traité de droit civil (sous la direction de J. Ghestin), Les sûretés personnelles, LGDJ, Paris, 2010, p. 2, nr. 2.

54 A se vedea, A.-S. Barthez, D. Houtcieff, Traité de droit civil (sous la direction de J. Ghestin), Les sûretés personnelles, p. 2, nr. 2.

55 A se vedea, G. Piette, Droit des sûretés. Sûretés personnelles. Sûretés réelles, $11^{\mathrm{e}}$ édition, Gualino, Issy-les-Moulineaux, 2017, p. 23.

${ }^{6}$ A se vedea, J. Deslauriers, A. Benadiba, Les sûretés au Québec, $2^{\mathrm{e}}$ édition, Wilson \& Lafleur, Montréal, 2018, p. 16, nr. 59.

57 În zilele de azi, alături de fideiusiune, Codul civil francez consacră alte două garanții personale: garanția autonomă (art. 2321 C. civ. fr.) și scrisoarea de intenție (art. 2322 C. civ. fr.). A se vedea, Ph. Simler, Cautionnement. Garanties autonomes. Garanties indemnitaires, p. 9, nr. 8 („,deux autres sûretés personnelles aujourd'hui consacrées par le Code civil: garantie autonome et lettre d’intention"). De altfel, art. 2287-1 C. civ. fr. este clar: garanțiile personale vizate sunt fideiusiunea, garanția autonomă și scrisoarea de intenție.

În România, art. 2279 C. civ. scoate în evidență că garanțiile personale sunt fideiusiunea, garanțiile autonome și alte feluri de garanții stabilite de lege. Garanțiile autonome „avute în minte" de Codul civil sunt două: scrisoarea de garanție (art. 2321 C. civ.) și scrisoarea de confort (art. 2322 C. civ.).

Bineînțeles, denumirea „scrisoare de intenție” desemnează, de asemenea, anumite documente ale negociatorilor, ce se manifestă în cursul perioadei precontractuale. A se vedea, H. Capitant, Fr. Terré, Y. Lequette, Les grands arrêts de la jurisprudence civile, tome 2, Obligations. Contrats spéciaux. Sûretés, 11 édition, Dalloz, Paris, 2000, p. 605. Astfel, pentru evitarea neclarităților sau confuziilor, expresia „scrisoare de confort” ar putea fi superioară celei de „scrisoare de intenție”, atunci când facem vorbire despre o anumită garanție personală.

\section{4}


garanția negativă constă în aceea că debitorul se îndatorează față creditor să nu constituie garanții personale, respectivul debitor se obligă să nu-și pună la bătaie patrimoniul în favoarea altei persoane; aşadar, o asemenea garanție negativă afectează ansamblul patrimoniului.

5. Clauza sau, adăugăm noi, garanția negativă referitoare la alienarea ${ }^{58}$ sau înstrăinarea unui bun poate fi interpretată, în funcție de redactarea ei, ca o clauză de inalienabilitate sau ca un simplu angajament de a nu face59. Într-adevăr, poftim o interogație: garanția negativă ce se referă la alienare este o veritabilă inalienabilitate sau o simplă obligație non facere $e^{60}$ ?

În măsura în care garanția negativă privitoare la înstrăinare este privită ca o inalienabilitate ${ }^{61}$, va trebui supusă dreptului comun al clauzelor de inalienabilitate şi va fi considerată eficace dacă este limitată în timp şi justificată de un interes serios şi legitim ${ }^{62}$ [art. 627 alin. (1) C. civ.]. Violarea unei garanții negative-clauză de inalienabilitate ar provoca, ca regulă generală, nulitatea relativă ${ }^{63}$ a contractului de înstrăinare (e.g., o vânzare).

58 Rose-Noëlle Schütz folosește expresiile „sûreté négative de ne pas aliéner” și „sûreté négative d'aliéner". A se vedea, R.-N. Schütz, Inaliénabilité, Répertoire de droit civil, 2014, nr. 94. Cele două sintagme promovează una și aceeași idee: nu este permisă transmiterea bunului. 59 A se vedea, M. Cabrillac, Ch. Mouly, S. Cabrillac, Ph. Pétel, Droit des sûretés, p. 478, nr. 644. 60 A se vedea, R.-N. Schütz, Inaliénabilité, Répertoire de droit civil, 2014, nr. 94.

${ }^{61}$ Claude Ferry scrie că inalienabilitatea unui bun poate fi stipulată astfel încât să se prezinte ca o garanție negativă. Astfel, ea își propune să-i garanteze unui creditor că un bun al debitorului nu va putea fi înstrăinat fără acordul respectivului creditor cât timp n-are loc plata completă a creanței. Sigur, este de la sine înțeles că creditorul nu vrea ca inalienabilitatea să-l privească. De altfel, dacă acest tip de inalienabilitate ar atrage insesizabilitatea, cea din urmă nu l-ar afecta pe creditor. Nimeni n-ar putea urmări bunul, în afară de acel creditor. Așadar, bunul ar fi afectat creanței sale, ceea ce ar presupune instituirea unei garanții fără text de lege. A se vedea, Cl. Ferry, L’insaisissabilité du bien stipulé inaliénable dans un acte à titre onéreux, RTD Civ. 2019.751, nr. 3 .

${ }^{62}$ A se vedea, Ph. Simler, Ph. Delebecque, Droit civil. Les sûretés. La publicité foncière, p. 24, nr. 33 .

63 A se vedea, M. Cabrillac, Ch. Mouly, S. Cabrillac, Ph. Pétel, Droit des sûretés, p. 478, nr. 644. 
După cum bine se ştie, nesocotirea unei stipulaţii de inalienabilitate poate atrage o nulitate relativă ${ }^{64}$ a contractului „nedelicat” și nepăsător față de stipulația cu pricina. În România, nişte texte situate în Codul civil [i.e., art. 2376, 2384 și 2396 C. civ.] nu pot fi ignorate. Asupra lor şi a unor comentarii doctrinare ${ }^{65}$ care le privesc ne vom concentra mai jos (infra., nr. 6).

Presupunând că garanția negativă ce vizează alienarea nu este decât un angajament de a nu face sau este interpretată într-o asemenea manieră, validitatea sa a părut incontestabilă preț de multă vreme ${ }^{66}$. La un moment dat, Casația franceză ${ }^{67} \mathrm{~s}-\mathrm{a}$ confruntat cu această situație factuală ${ }^{68}$ : la Caisse des Dépôts et Consignations (i.e., CDC) le-a consimțit domnului și doamnei $\mathrm{X}$ două împrumuturi imobiliare, în termenii cărora împrumutatul se angaja „să locuiască personal și în mod continuu imobilul vizat de împrumut şi să nu-l vândă, nici să-l închirieze făă acordul împrumutătorului”’99. Termenii celor două împrumuturi stipulau că „în cazul în care imobilul va fi închiriat sau vândut în tot sau în parte, fără acordul împrumutătorului”, toate sumele

\footnotetext{
64 A se vedea, Fr. Terré, Ph. Simler, Droit civil. Les biens, 8 édition, Dalloz, Paris, 2010, p. 138, nr. 136; Commentaires du Ministre de la Justice, in J.-L. Baudouin, Y. Renaud, Code civil du Québec annoté, tome 1, $15^{\mathrm{e}}$ édition, Wilson \& Lafleur, Montréal, 2012, p. 1484 (,[1] a nullité dont il est question est une nullité relative"). Totodată, a se vedea, C. Bîrsan, Drept civil. Drepturile reale principale, ediția a 3-a, revizuită și actualizată, Hamangiu, București, 2017, p. 95, nr. 102. 65 A se vedea, S. I. Vidu, Garanțiile executării obligațiilor, in L. Pop, I.-Fl. Popa, S. I. Vidu, Curs de drept civil. Obligațiile, Universul Juridic, București, 2015, p. 619, nr. 581. De asemenea, a se vedea, P. Vasilescu, Drept civil. Obligații, ediția a 2-a revizuită, Hamangiu, București, 2017, p. 179 [inter alia, profesorul Vasilescu pomenește clauze de inalienabilitate privitoare la bunul ipotecat și face trimitere la art. 2384 alin. (1) C. civ.].

${ }^{66}$ A se vedea, M. Cabrillac, Ch. Mouly, S. Cabrillac, Ph. Pétel, Droit des sûretés, p. 479, nr. 644.

${ }^{67}$ A se vedea, Civ. ${ }^{\text {re }}, 13$ déc. 2005.

68 Pentru expresia ,factual situation”, a se vedea, U. A. Mattei, T. Ruskola, A. Gidi, Schlesinger's Comparative Law. Cases - Text - Materials, seventh edition, Foundation Press, New York, 2009, p. 99.

${ }^{69}$ A se vedea, Civ. $1^{\text {re }}, 13$ déc. 2005.
} 
datorate de împrumutat vor deveni exigibile de plin drept ${ }^{70}$. Împrumutații au închiriat bunul fără să-l avertizeze pe împrumutător ${ }^{71}$. CDC a solicitat aplicarea clauzei de exigibilitate a sumelor datorate ${ }^{72}$. Soții X au contestat validitatea clauzelor litigioase ${ }^{73}$.

Prevederea contractuală în temeiul căreia erau prohibite vânzarea şi închirierea, în absența acordului împrumutătorului, era o garanție negativă; ea interzicea, cumulativ, două operaţiuni (i.e., înstrăinarea şi locaţiunea). Clauza ce făcea vorbire despre exigibilitatea de plin drept a sumelor datorate era una care stabilea remediul pentru încălcarea garanției negative: decăderea din termen 74 .

Instanța supremă din Franța75 a decis că clauzele contractului de împrumut relative la interdicția de locațiune, sub amenințarea exigibilității anticipate a împrumutului, sunt interzise de art. 6 și vechiul art. 1172 C. civ. fr. ${ }^{76}$, deoarece reprezintă o atingere adusă principiului recunoscut constituțional și enunțat de art. 544 C. civ. fr.: posibilitatea unei persoane să dispună de bunul său în mod absolut777. Observăm că judecătorii francezi au

${ }^{70}$ A se vedea, Civ. $1^{\text {re }}, 13$ déc. 2005 .

${ }^{71}$ A se vedea, Civ. $1^{\text {re }}, 13$ déc. 2005.

${ }^{72}$ A se vedea, Civ. $1^{\text {re }}, 13$ déc. 2005.

73 A se vedea, Civ. $1^{\text {re }}, 13$ déc. 2005.

74 Doi comentatori ai deciziei din 13 decembrie 2005 a Casației franceze menționează decăderea din termen (i.e., déchéance du terme). A se vedea, J. Mestre, B. Fages, Des clauses originales mais illicites au regard des droits fondamentaux, RTD Civ. 2006.557.

75 Curtea de Casație este cea mai înaltă jurisdicție a ordinului judiciar; plasată în vârful ierarhiei, ea este denumită „Curtea supremă”. A se vedea, R. Perrot, Institutions judiciaires, $12^{\mathrm{e}}$ édition, Montchrestien, Paris, 2006, p. 176, nr. 216.

76 Din câte se pare, în 2016, vechiul art. 1172 C. civ. fr. s-a metamorfozat în art. 1304-1 C. civ. fr. A se vedea, G. Wiederkehr, X. Henry, A. Tisserand-Martin, G. Venandet, P. Ancel, P. Guiomard, Code civil Annoté, 118 édition, Dalloz, Paris, 2018, p. 1716.

77 A se vedea, Civ. ${ }^{\text {re }}, 13$ déc. 2005.

\section{7}


insistat asupra unei porțiuni a garanției negative: cea referitoare la interdicția de locațiune. Ei au procedat astfel, întrucât partea respectivă a fost nesocotită, aşa cum indică faptele. Nu vedem, însă, niciun motiv pentru care afirmația Casației să nu fie aplicabilă porțiunii, din garanția negativă, privitoare la alienare (i.e., la vânzare).

Unii autori78 îşi canalizează atenția asupra deciziei Casaţiei din 13 decembrie $2005^{79}$ și proclamă că această hotărâre nu condamnă, la nivel de principiu, clauza prin care este asumat angajamentul de a nu închiria, ci îl invită pe judecător să aprecieze în ce măsură atingerea adusă dreptului de proprietate este legitimă şi proporțională față de obiectivul urmărit ${ }^{80}$. Cel mai probabil, la fel stau lucrurile în privința porțiunii din garanția negativă ce viza vânzarea: ea nu este combătută în principiu, ci judecătorul se va lansa într-o analiză de legitimitate și proporționalitate.

Admițând că o garanție negativă de alienare este validă și că este un agajament de a nu face ori obligație non facere, remediile aflate la dispoziția creditorului, în situația încălcării acestei garanții negative, ar fi următoarele: daunele-interese la care poate fi ținut debitorul ${ }^{81}$; dacă garanția negativă de înstrăinare este inserată într-un împrumut, eventual ar putea interveni rezoluțiunea contractului, ceea ce echivalează cu decăderea din termen ${ }^{82}$ (i.e., cu o exigibilitate anticipată); creditorul ar mai avea deschisă calea daunelorinterese, posibil de obținut de la cocontractantul debitorului, dacă acest

\footnotetext{
${ }^{78}$ A se vedea, M. Cabrillac, Ch. Mouly, S. Cabrillac, Ph. Pétel, Droit des sûretés, p. 479, nr. 644. 79 Civ. $1^{\text {re }}, 13$ déc. 2005.

${ }^{80}$ A se vedea, M. Cabrillac, Ch. Mouly, S. Cabrillac, Ph. Pétel, Droit des sûretés, p. 479, nr. 644. ${ }^{81}$ A se vedea, M. Cabrillac, Ch. Mouly, S. Cabrillac, Ph. Pétel, Droit des sûretés, p. 479, nr. 644. ${ }^{82}$ A se vedea, M. Cabrillac, Ch. Mouly, S. Cabrillac, Ph. Pétel, Droit des sûretés, p. 479, nr. 644.
} 
partener contractual a cooperat în cunoștință de cauză la nesocotirea garanției negative de înstrăinare văzută ca obligație de a nu face ${ }^{83}$.

La urma-urmei, în ipoteza garanției negative de alienare, nu poate fi lepădată remarca autoarei Rose-Noëlle Schütz: prudența ne îndeamnă să reținem natura de obligație de a nu face ${ }^{84}$.

6. Art. 2376 C. civ., inclus în rândul dispozițiilor generale dedicate ipotecii, dictează că actele de dispoziție asupra bunului ipotecat sunt valabile chiar dacă dobânditorul lucrului cunoaşte stipulația din contractul de ipotecă ce interzice transferul. „Clauza de inalienabilitate” este denumirea marginală a textului de lege. Art. 2384 alin. (1) C. civ. ${ }^{85}$, înglobat într-o secțiune intitulată „Ipoteca imobiliară”, admite, la fel ca art. 2376 C. civ., validitatea actelor de dispoziție asupra bunului, în ciuda unei stipulații din convenția de ipotecă imobiliară ce nu îngăduie transmiterea şi chiar dacă dobânditorul lucrului ipotecat cunoștea stipulația prohibitivă. Alin. (2) al art. 2384 C. civ. consideră nescrise clauzele ce impun debitorului plata anticipată a obligației garantate sau executarea unei alte obligații prin faptul constituirii unei alte garanții asupra bunului deja ipotecat. „Clauzele de inalienabilitate” este sintagma aflată în marginea art. 2384 C. civ. Art. 2396 C. civ. este întâlnit într-o secțiune închinată ipotecii mobiliare, iar al său alin. (3) este identic cu alin. (2) al art. 2384 C. civ.

Un autor, făcând referire la art. 2376 și 2384 C. civ., este de părere că clauza ce interzice transferul bunului grevat ar fi una de inalienabilitate

\footnotetext{
83 A se vedea, M. Cabrillac, Ch. Mouly, S. Cabrillac, Ph. Pétel, Droit des sûretés, p. 479, nr. 644. 84 A se vedea, R.-N. Schütz, Inaliénabilité, Répertoire de droit civil, 2014, nr. 94.

85 Poate că art. 2384 alin. (1) C. civ., prin cuvântul „acte” cuprins în expresia „stipulația din contractul de ipotecă ce interzice asemenea acte", se referă la acte de dispoziție de înstrăinare ori de transfer. Bineînțeles, „actele de dispoziție”, menționate la începutul art. 2384 alin. (1), ar fi, probabil, acte de dispoziţie de transmitere sau transfer.
} 
valabilă între părți, dar inopozabilă dobânditorului ${ }^{86}$. Sigur, scriitorul acesta ne lasă să știm că am fi în prezența unei inalienabilități care deviază de la art. 629 C. civ. ${ }^{87}$ (i.e., nulitatea actului juridic ce încalcă o clauză de inalienabilitate). Un alt doctrinar, țintind art. 2384 alin. (1) C. civ., aduce în discuție clauzele de inalienabilitate ${ }^{88}$.

După mintea noastră, în ciuda denumirilor marginale ale art. 2376 și 2384 C. civ., cele două texte n-au nimic de-a face cu clauzele de inalienabilitate. Într-adevăr, ne este cu neputință să „digerăm” o clauză de inalienabilitate care, deși ar fi cunoscută de dobânditorul bunului grevat astfel cum acceptă art. 2376 și 2384 alin. (1), i-ar fi, totuși, inopozabilă acestuia. Apoi, ne vine dificil să ne închipuim o clauză de inalienabilitate care derogă de la art. 629 C. civ., adică, o inalienabilitate ce este într-atât de vlăguită şi lipsită de potență încât călcarea sa în picioare să nu atragă nulitatea relativă a actului de înstrăinare.

În ceea ce ne privește, art. 2376 și 2384 alin. (1) C. civ. consacră garanții negative de alienare ca obligații non facere. Așa fiind, va fi exlusă nulitatea relativă a actului juridic de înstrăinare ce încalcă o asemenea garanție negativă; altfel spus, actele de dispoziție vor fi valabile [art. 2376 și 2384 alin. (1) C. civ.]. Totuşi, încălcarea garanției negative-angajament de a nu face printr-un act de înstrăinare l-ar îndreptăți pe creditor la alte remedii: e.g., daune-interese împotriva debitorului-constituitor al ipotecii; dauneinterese împotriva cocontractantului debitorului (i.e., dobânditorului bunului

\footnotetext{
86 A se vedea, S. I. Vidu, Garanțiile executărï obligațiilor, in L. Pop, I.-Fl. Popa, S. I. Vidu, Curs de drept civil. Obligațiile, p. 619, nr. 581, nota de subsol nr. 2.

87 A se vedea, S. I. Vidu, Garanțiile executării obligațiilor, in L. Pop, I.-Fl. Popa, S. I. Vidu, Curs de drept civil. Obligațiile, p. 619, nr. 581, nota de subsol nr. 3.

${ }^{88}$ A se vedea, P. Vasilescu, Drept civil. Obligații, p. 179.
} 
grevat), atunci când acesta cooperează în cunoștință de cauză la nesocotirea garanției negative.

Așa cum am văzut mai sus (supra., nr. 4), garanția negativă poate interzice constituirea de garanțiiis: debitorul își poate lua angajamentul de a nu constitui o garanție asupra unui anumit bun ${ }^{90}$. Acest tip de garanție negativă îi pare inacceptabil legiuitorului român, deoarece clauzele care stabilesc remedii'11, în cazul nerespectării sale, sunt reputate nescrise [art. 2384 alin. (2) şi 2396 alin. (3) C. civ.]. E.g., într-un contract de ipotecă imobiliară sau mobiliară, este inserată o garanție negativă, potrivit căreia debitorul-constituitor se obligă să nu constituie o altă garanție, în favoarea altui creditor, asupra bunului deja ipotecat. Totodată, în convenție, este plasată o clauză ce arată că, în situația violării garanției negative prin constituirea unei alte garanții, creditorul are la îndemână remediul plății anticipate sau exigibilității anticipate (i.e., decăderii din termen). Clauza care stabilește un astfel de remediu este considerată nescrisă [art. 2384 alin. (2) și 2396 alin. (3) C. civ.], aşa că garanția negativă nu servește la nimic; creditorul nu are posibilitatea să obțină remediul stabilit în caz de batjocorire a garanției negative.

7. Garanția negativă nu-i este străină tradiției de Common Law. În engleză, ea este botezată astfel: negative pledge. În mod obișnuit, o garanție

\footnotetext{
${ }^{89}$ A se vedea, M. Cabrillac, Ch. Mouly, S. Cabrillac, Ph. Pétel, Droit des sûretés, p. 478, nr. 644. ${ }^{90}$ A se vedea, D. Legeais, Droit des sûretés et garanties du crédit, p. 33, nr. 23.

${ }^{91}$ Avem în gând remedii precum plata sau exigibilitatea anticipată (i.e., decăderea din termen) ori „plata vreunei alte obligații” [e.g., daune-interese].
} 
negativă ar putea suna așa: „împrumutatul nu va crea, nici nu va permite să subziste vreo garanție asupra vreunui bun de-al său”92.

În Central Hanover Bank \& Trust Co. v. Kelly, putea fi notată o garanție negativă de a nu constitui alte garanții93 (i.e., mortgage sau pledge). În Kelly, o pretenție privitoare la un equitable lien ${ }^{94}$, precum și una referitoare la „ceva în natura unei equitable servitude 95 ”, au fost sprijinite pe clauza de garanție negativă ${ }^{96}$. Curtea a subliniat că niciun equitable lien nu poate răsări din garanția negativă97. Mai mult, în Kelly (i.e., un litigiu din 1935), instanța evidențiază că n-a fost citat și nici descoperit vreun caz în care să se decidă că

92 A se vedea, R. Hardwick, The negative pledge and disposal restrictions: carve-outs and remedies for breach, Butterworths Journal of International Banking and Financial Law, september 2017, p. 510.

93 A se vedea, Central Hanover Bank \& Trust Co. v. Kelly, 11 F. Supp. 497 (1935), nota de subsol $\mathrm{nr}$. [2] (,[t] he negative pledge clause reads: [t] he Company hereby covenants and agrees with the holder hereof that so long as this debenture shall be outstanding and provision for the payment thereof shall not have been made it will not mortgage or pledge any of its property unless the instrument creating such mortage or pledge shall provide that this debenture shall be secured thereby equally and ratably with all other obligations issued or to be issued thereunder, except that the company without so securing this debenture (a) may at any time mortgage or pledge any of its property for the purpose of securing loans to the Company contracted in the usual course of business for periods not exceeding one year, and (b) may, in order to secure the purchase price or part thereof of any property which it may hereafter acquire, mortgage or pledge any or all of such acquired property").

94 Black's Law Dictionary pune în lumină că un equitable lien este un drept, ce poate fi valorificat numai în Equity, de a vedea o pretenție satisfăcută cu ajutorul unui fond particular sau al unui bun specific, fără ca cel interesat să aibă posesia fondului sau bunului. A se vedea, B. A. Garner (editor in chief), Black's Law Dictionary, ninth edition, West, 2009, p. 1007.

95 Potrivit Black's Law Dictionary, o equitable servitude (de asemenea denumită restrictive covenant) este un acord privat ce restrânge utilizarea sau ocuparea bunurilor imobile (i.e., real property). A se vedea, B. A. Garner (editor in chief), Black's Law Dictionary, p. 421.

96 A se vedea, Central Hanover Bank \& Trust Co. v. Kelly, 11 F. Supp. 497 (1935) (,[t] his claim (i.e., the claim of an equitable lien on assets; nota ns., A.T.), as well as that of „something in the nature of an equitable servitude" is rested on the negative pledge clause ...").

97 A se vedea, Central Hanover Bank \& Trust Co. v. Kelly, 11 F. Supp. 497 (1935). 
o promisiune negativă (i.e., negative covenant) ar fi capabilă să genereze un equitable lien ${ }^{9}$. Totodată, în Kelly, s-a hotărât că punctul de vedere, conform căruia promisiunile ar fi creat „ceva în natura unei equitable servitude”, este, de asemenea, nefondat, chiar dacă ar fi aplicat promisiunii de garanție negativă (i.e., the negative pledge covenant $\left.{ }^{99}\right)^{100}$.

În First Wyoming Bank, Casper v. Mudge, familia Mudge (i.e., the Mudges) a încheiat un acord prin care îi vindea lui Redding afacerea corporativă de familie ${ }^{101}$. Acordul scris a inclus transferul părților, deținute de familia Mudge, în compania M \& M Welding, Inc., împreună cu alte valori ale companiei (i.e., inventory, equipment, the business site real property) ${ }^{102}$. În plus, acordul cuprindea ceea ce curtea numește $a$ nonencumbrance covenant clause $^{103}$, adică, zicem noi, o garanție negativă de a nu constitui alte garanții (i.e., mortgage) asupra bunurilor companiei M \& M Welding, Inc. sau asupra celor ale unei eventuale corporații succesoare. Sigur, cumpărătorul mai avea de plătit o parte din preț. Acesta (i.e., cumpărătorul Redding) a preluat M \& M Welding ${ }^{104}$. Aproape imediat, Redding i-a solicitat apelantului (i.e., First

${ }^{8}$ A se vedea, Central Hanover Bank \& Trust Co. v. Kelly, 11 F. Supp. 497 (1935).

$99 \mathrm{O}$ covenant este un acord formal sau promisiune de a face sau a nu face ceva. A se vedea, $\mathrm{B}$. A. Garner (editor in chief), Black's Law Dictionary, p. 419 („[a] formal agreement or promise, usu. in a contract or deed, to do or not to do a particular act").

100 A se vedea, Central Hanover Bank \& Trust Co. v. Kelly, 11 F. Supp. 497 (1935).

${ }^{101}$ A se vedea, First Wyoming Bank, Casper v. Mudge, 748 P.2d 713 (1988).

${ }^{102}$ A se vedea, First Wyoming Bank, Casper v. Mudge, 748 P.2d 713 (1988).

103 A se vedea, First Wyoming Bank, Casper v. Mudge, 748 P.2d 713 (1988) (,the document contained a nonencumbrance covenant clause ... which provided: [i]t is agreed that the assets of $M \& M$ Welding, Inc. ... or its successor corporation shall not be mortgaged for more than the presently existing indebtedness without Sellers' consent until the total purchase price herein agreed to be paid shall have been paid in full [;] [s]uch consent shall not be unreasonably withheld").

104 A se vedea, First Wyoming Bank, Casper v. Mudge, 748 P.2d 713 (1988) („the buyer took over the operation of $M \& M$ Welding"). 
Wyoming Bank, Casper) un împrumut în cuantum de $\$ 100.000^{105}$. Ofițerilor băncii, responsabili cu împrumuturile (i.e., the Bank's lending officers), le-a fost înmânată o copie nesemnată a acordului de cumpărare dintre familia Mudge și Redding, care conținea garanția negativă ${ }^{106}$. Banca a obținut o garanție ce viza valori ale M \& M Welding (i.e., a security interest in the inventory and equipment) ${ }^{107}$. Curtea a decis că au existat suficiente dovezi care să permită concluzia că banca avea cunoștință de termenii acordului de cumpărare $^{108}$ dintre familia Mudge și Redding; într-adevăr, banca știa de garanția negativă de a nu constitui alte garanții, conținută de acordul de cumpărare. Finalmente, băncii (i.e., entitate străină față de acordul dintre familia Mudge şi Redding) i-a fost pus în spinare un tort: intentional interference with a contract ${ }^{109}$.

În Pullen v. Abalcheck Pty. Ltd. (i.e., un caz australian), reclamanții şi pârâtul au încheiat un document numit deed of charge ${ }^{110}$. Documentul sau, spunem noi, charge ${ }^{111}$ pretindea să fie o garanție cu privire la bani datorați reclamanților de către pârât ${ }^{112}$; banii erau garantați de charge. Secțiunea

105 A se vedea, First Wyoming Bank, Casper v. Mudge, 748 P.2d 713 (1988).

${ }^{106}$ A se vedea, First Wyoming Bank, Casper v. Mudge, 748 P.2d 713 (1988).

107 A se vedea, First Wyoming Bank, Casper v. Mudge, 748 P.2d 713 (1988).

${ }^{108}$ A se vedea, First Wyoming Bank, Casper v. Mudge, 748 P.2d 713 (1988).

109 A se vedea, First Wyoming Bank, Casper v. Mudge, 748 P.2d 713 (1988) (,[t]his case, in classical terms, fits the historical perspective of this tort (i.e., intentional interference with a contract; nota ns., A.T.) theory").

${ }^{110}$ A se vedea, Pullen v. Abalcheck Pty. Ltd., Supreme Court of New South Wales, 20 September 1990.

${ }^{111}$ Charge este o garanție, ce poate avea ca obiect mobile sau imobile. A se vedea, V. Sagaert, Security Interests, in S. van Erp, B. Akkermans (editors), Cases, Materials and Text on National, Supranational and International Property Law, Hart Publishing, 2012, p. 449.

${ }^{112}$ A se vedea, Pullen v. Abalcheck Pty. Ltd., Supreme Court of New South Wales, 20 September 1990. 
205A din Companies Code 1981 a făcut aşa încât charge să fie lipsită de efecte (i.e., void $)^{113}$. Totuși, secțiunea cu pricina nu a afectat obligațiile personale ale pârâtului, asumate prin deed of charge ${ }^{114}$. Clauza 6.1 din charge vorbea, inter alia, despre o garanție negativă de a nu constitui alte garanții (i.e., mortgage sau charge), de a nu vinde, de a nu dispune sau de a nu realiza alte operațiuni privitoare la unele bunuri ${ }^{115}$. În Pullen, ni se spune că aproape toate deciziile referitoare la garanții negative din Statele Unite și dicta ${ }^{116}$ cuprinse în decizii din alte părți arată că o clauză de garanție negativă constituie o promisiune personală (i.e., a personal covenant) ${ }^{117}$. Fiind o promisiune personală, garanția negativă nu putea fi eliminată de secțiunea 205(A) din Companies Code 1981. Din câte se pare, în Pullen, charge ${ }^{118}$ a fost lipsită de efecte, dar

${ }^{113}$ A se vedea, Pullen v. Abalcheck Pty. Ltd., Supreme Court of New South Wales, 20 September 1990.

${ }^{114}$ A se vedea, Pullen v. Abalcheck Pty. Ltd., Supreme Court of New South Wales, 20 September 1990.

115 A se vedea, Pullen v. Abalcheck Pty. Ltd., Supreme Court of New South Wales, 20 September 1990 (,[c]lause 6.1 of the charge provided that the charge thereby given was a fixed charge on certain assets and a floating charge on others, then continued with these words: ... the Company shall not be at liberty to create any mortgage or charge thereon, whether fixed or floating, ranking in priority to or pari passu with this charge, or to sell, dispose of or otherwise deal with the property and assets subject to afloating charge, except in the ordinary course of its business...”; subl. ns., A.T.).

116 Obiter dicta este forma la plural a sintagmei obiter dictum. Obiter dictum semnifică „ceva zis în treacăt”. A se vedea, B. A. Garner (editor in chief), Black's Law Dictionary, p. 1177.

${ }^{117}$ A se vedea, Pullen v. Abalcheck Pty. Ltd., Supreme Court of New South Wales, 20 September 1990.

118 Agnew and Another $v$. Commisioner of Inland Revenue a fost un caz în care Privy Council a formulat această problemă: charge este, in casu, o fixed charge sau o floating charge? A se vedea, Agnew and Another v. Commisioner of Inland Revenue, Privy Council (New Zealand), [2001] 3 WLR 454, in S. van Erp, B. Akkermans (editors), Cases, Materials and Text on National, Supranational and International Property Law, p. 462, nota de subsol nr. 55. În ochii lui Vincent Sagaert, Privy Council a decis că totul se rezumă la controlul asupra bunurilor vizate de charge (i.e., the charged assets); dacă chargee (i.e., cel căruia îi aparține charge) se bucură de control, vom avea de-a face cu o fixed charge; în măsura în care chargor (i.e.,

975 
garanția negativă din documentul de charge a fost menținută. Curtea crede că ar trebuie să presupună, în contextul procesului derulat înaintea sa, că garanția negativă poate exista independent de charge ${ }^{119}$. O interesantă problemă, ivită în Pullen, a fost posibilitatea oferirii unei injunction ${ }^{120}$ pentru a preveni nesocotirea garanției negative ${ }^{121}$. Instanța a fost de părere că ar trebui să facă uz de injunction ${ }^{122}$.

8. Ortodoxia va fi abandonată: în lucrarea noastră, concluziile explicite sunt inobservabile. $\mathrm{O}$ astfel de manieră de a proceda este tolerabilă, credem: „l'écrivain est maître de ce qu’il écrit”'123, iar ceea ce noi am scris (i.e., studiul de față) va fi fără concluzii.

constituitorul charge) este în control, ne vom lovi de ofloating charge. A se vedea, V. Sagaert, Security Interests, in S. van Erp, B. Akkermans (editors), Cases, Materials and Text on National, Supranational and International Property Law, p. 464.

${ }^{119}$ A se vedea, Pullen v. Abalcheck Pty. Ltd., Supreme Court of New South Wales, 20 September 1990 (,... I should merely assume for the purpose of these proceedings that the negative pledge can exist independently of the charge").

${ }^{120}$ Injunction este un equitable remedy croit de Chancery, ce îi interzicea pârâtului să se angajeze într-o activitate viitoare și rea (i.e., future tortious misconduct) care amenința să-l păgubească pe reclamant. A se vedea, E. Bodenheimer, J. B. Oakley, J. C. Love, An Introduction to the Anglo-American Legal System. Readings and Cases, fourth edition, West, 2004, p. 50. Desigur, mai rar, injunction poate fi întâlnită în materie contractuală. A se vedea, G. P. Fletcher, S. Sheppard, American Law in a Global Context. The Basics, Oxford University Press, 2005, p. 426 (,[o]nly if the performance has a unique object ... can one think about injunction in equity to compel the performance").

${ }^{121}$ A se vedea, Pullen v. Abalcheck Pty. Ltd., Supreme Court of New South Wales, 20 September 1990.

${ }^{122}$ A se vedea, Pullen v. Abalcheck Pty. Ltd., Supreme Court of New South Wales, 20 September 1990 („I think I should grant an injunction in the instant case”).

${ }^{123}$ A. Fouillée, La science sociale contemporaine, Librairie Hachette et Cie, Paris, 188o, p. 262. 